Article

\title{
Thermophilic Co-Fermentation of Wood Wastes and High in Nitrogen Animal Manures into Bio-Methane with the Aid of Fungi and Its Potential in the USA
}

\author{
John G. Ingersoll \\ ECOCORP, 1211 South Eads Street, Suite 803, Arlington, VA 22202, USA; jgingersoll@ecocorp.com; \\ Tel.: +1-202-999-0840
}

Received: 26 July 2020; Accepted: 10 August 2020; Published: 17 August 2020

\begin{abstract}
A novel process is proposed whereby wood wastes from forest tree mortalities and improved forest management are co-digested with high in nitrogen content animal manures to yield bio-methane along with nitrogen, phosphorous, and potassium bio-fertilizers. The process mimics the well-known wood conversion to methane process in lower termites but relies on thermophilic fungi, bacteria, and archaea instead. It is based on the modified state-of-the art two-step, hyperthermophilic $\left(70{ }^{\circ} \mathrm{C}\right)$ hydrolysis and thermophilic $\left(55^{\circ} \mathrm{C}\right)$ fermentation, dry $(30 \% \mathrm{TS})$, anaerobic digestion technology with a high organic loading and shortened retention time. The process is augmented with the thermophilic fermentation of carbon dioxide in the biogas into secondary bio-methane by employing hydrogen produced via wind-powered electrolysis. The entire process comprised of five distinct steps is designated as "Wood to Methane $3+2$ ". An industrial type, standardized plant unit has been developed that can be employed in a modular fashion. The implementation of these plant units across the US, utilizing the estimated waste wood potential along with $3 / 4$ of the produced poultry and pig manure, would generate the equivalent of $2 / 3$ of transportation fuel consumption and would supply about $11 \%$ of current US energy use per annum. The produced bio-methane can be cost-competitive only if it is employed as a transportation fuel to replace fossil gasoline and diesel fuels. The required annual investment over a 20 -year period is well within the means of the US economy in a public-private development partnership.
\end{abstract}

Keywords: thermophilic bacteria; archaea and fungi; wood; fermentation; nitrogen-rich animal manures; modular industrial plant design; bio-methane; carbon dioxide; hydrogen; bio-fertilizers; wind power; water electrolysis

\section{Introduction}

Wood is a fibrous but porous structural organic material found in the stems and roots of trees and other woody plants [1]. In a living tree, wood performs a support function, enabling the plant to stand up by itself and conveying water and nutrients between the leaves, other growing tissues, and the roots. It is common to classify wood as either softwood (e.g., conifers) or hardwood (e.g., broad-leaved deciduous trees in temperate climates). The chemical composition of wood varies from species to species, but is approximately $50 \%$ carbon, $42 \%$ oxygen, $6 \%$ hydrogen, $1 \%$ nitrogen, and $1 \%$ of other macro-elements (mainly calcium, potassium, sodium, magnesium, iron, and manganese) as well as micro-elements (sulfur, chlorine, silicon, phosphorus, and others) [2]. The composition of wood, or of woody biomass as it is also known, consists of six major components: cellulose, hemicellulose, lignin, mineral components, extractives, and water. Water may constitute about $40 \%$ to $50 \%$ by weight of freshly cut wood, but it can be reduced to almost one quarter as much at about $12 \%$, if the wood is dried thoroughly in air. Cellulose, a crystalline polymer derived from glucose, which is a six-carbon 
sugar, constitutes about $41-43 \%$ of dry matter in wood. Hemicellulose, which varies from about $20 \%$ in deciduous trees to near $30 \%$ in conifers, both on a dry matter basis, consists mainly of five-carbon sugars that are linked in an irregular, i.e., amorphous, manner. Lignin, which varies from around $27 \%$ in conifers to $23 \%$ in deciduous trees, both on a dry basis, is a polymer of phenolic compounds (aromatic rings) that confer its hydrophobic properties. It should be noted that the difference between hardwood and softwood is reflected in the phenolic composition of the constituent lignin component [3]. Wood may also contain, up to $5 \%$ by dry weight, a number of low molecular weight organic compounds called extractives. These compounds comprise fatty acids, resins, waxes, and terpenes and their extraction provides valuable chemicals, among others tannin, tall oil, turpentine, and rosin $[4,5]$.

The molecules of cellulose, hemicellulose, and lignin are interwoven in such a way that direct strong chemical linkages exist between the lignin matrix and cellulose as well as hemicellulose, making wood a very stable material resisting degradation by external factors, particularly microbial ones. Because of its chemical stability and its structural mechanical strength, wood has been historically employed as construction material for houses, furniture, utensils, tools, weapons, and boats [6]. A major use of wood in recent times is for paper manufacturing that necessitates the separation of the lignin from the cellulose, from which paper is made, via the use of chemical processes (Kraft Process). Wood has had obviously a long history of being used as fuel via combustion, which continues to this day, mostly in rural areas of the world [7]. Hardwoods are preferred over softwoods because they create less smoke and burn longer. Wood combustion has been the only practical method to extract its energy, but it is also by-and-large an air-polluting and inefficient process in a modern economy. The employment of a microbial-based process to extract the energy in wood as a gaseous fuel, i.e., bio-methane, is possible as presented herein.

\section{The Magnitude of the Wood Waste Resource}

As of 2020, the growing stock of forests worldwide stands at about 557 billion $\mathrm{m}^{3}$ and approximately 4.3 billion $\mathrm{m}^{3}$ of wood is harvested annually [8]. Dominant uses are for building construction, furniture, papermaking, and heating fuel [9]. Forestland in the United States covers 33\% of the surface area of the country or about 329 million hectares, of which $57 \%$ is privately owned and $67 \%$ of it is in commercial use for timber extraction [10]. The growing stock in 2017 was about 27 billion $\mathrm{m}^{3}$, of which 16 billion $\mathrm{m}^{3}$ were softwoods and about 11 billion $\mathrm{m}^{3}$ were hardwoods. The annual removal rate is about 450 million $\mathrm{m}^{3}$ and the annual mortality rate is about 200 million $\mathrm{m}^{3}$, while the annual new growth amounts to almost 700 million $\mathrm{m}^{3}$, thereby leading to small net annual growth of the stock. Wood supplies a little over $2 \%$ of the annual energy use in the United States, amounting to 2.356 quads ( 1 quad $=1.000 \times 10^{15}$ $\mathrm{Btu}=1.055 \times 10^{18} \mathrm{~J}$ ), with $65 \%$ of it for industrial uses (wood products and paper manufacturers), $22 \%$ for residential uses (home heating and cooking), $9 \%$ for power generation, and $4 \%$ for commercial uses (building heating) [11]. Assuming an average dry wood energy content of $20 \mathrm{GJ}$ per $\mathrm{mt}$, we calculate that the amount of wood used today in the country for energy production is about 125 million $\mathrm{mt}$. By comparison, the dry wood mass of the harvested annually 450 million $\mathrm{m}^{3}$ is about 225 million $\mathrm{mt}$, assuming an average dry wood density of $0.5 \mathrm{mt}$ per $\mathrm{m}^{3}$. This suggests that about 100 million $\mathrm{mt}$ of dry wood is used in the United States annually for building construction materials (56\%), furniture and other wood products $(10 \%)$, and paper manufacturing (34\%). The annual wood mortality has a dry mass of about 100 million $\mathrm{mt}$, is not collected currently, and is left on the ground to decay over time.

A complimentary and quite significant source of wood biomass would come from the thinning and improvement cuttings that are needed to increase the production of quality timber, as well as the thinning of forest standing to reduce the danger of fire. Studies have shown that the amount of dry wood that could be removed from forest thinning could be quite significant [12]. Moreover, there are various ways of forest thinning [13]. Thus, the amount of dry wood available to be obtained by forest thinning across the country would be on the order of four times that of the mortality rate or about 400 million dry $\mathrm{mt}$ of biomass per year, including the mortality amount. Thinning will be carried out initially on a rotation basis of 20 years average or about 15 million hectares per year. Thinning will 
obviously subsume mortality. It should be noted that forest thinning would result in an increase in the rate of growth of trees in the forested land that would eventually more than offset the thinning itself. In the long run, i.e., in 20 years time or after one full rotation of initial thinning across all forested land, the annual growth would rise to be 1250 million $\mathrm{m}^{3}$ per year. Of these, 450 million $\mathrm{m}^{3}$ will be harvested annually to maintain the current uses and 800 million $\mathrm{m}^{3}$ will be used annually as the feedstock for an advanced biofuel via fermentation as it is discussed in this paper. Thus, the size of the present forest stock will be maintained indefinitely.

It should be noted that environmental groups have raised strong objections to forest thinning as constituting a license to cut old tree stands. As a result, no long-term plans for forest thinning have been implemented, particularly in the southwest where the forested lands are highly susceptible to fires due to the prevailing dry climate. The devastating fires in California in recent years are a testimony to the no forest thinning implementation in the state. Such fires not only result in the destruction of valuable wood biomass but also generate huge amounts of greenhouse gas emissions. Alternatively, the forest land of the United States, if managed properly, can supply, in a sustainable fashion, an additional large amount of wood biomass up 400 million dry $\mathrm{mt} / \mathrm{yr}$, while maintaining the current forest stock unchanged, for the exclusive production of bio-methane as an advanced transportation fuel as well as a replacement of the fossil natural gas used today.

\section{Wood Fermentation to Bio-Methane}

Wood represents an abundant, carbon-neutral renewable resource and woody materials have been of intense interest as a source of renewable energy. However, the large-scale combustion of wood to extract energy is no longer deemed to be a most efficient and environmentally desirable choice and other pathways must be developed [14]. One very promising such pathway is the microbial fermentation or anaerobic digestion of wood and wood wastes into bio-methane as an advanced transportation fuel, commercial grade phosphate, nitrogen and potash bio-fertilizers, and green carbon dioxide as either an industrial gas or better yet, as a feedstock for other chemicals and fuels, including additional bio-methane production with the aid of wind and solar power.

As it has been mentioned, wood is highly resistive to microbial decomposition. In fact, there is no known single microorganism that can directly attack wood in its natural state and decompose it in order to extract its energy content. However, we do observe that wood decomposes naturally, albeit slowly, in most instances. Thus, wood microbial decomposition is possible but relies on a fairly complex symbiotic natural process comprised of several organisms, some macro and most micro ones, as researchers have been trying to elucidate in recent years [15]. This complex symbiotic natural process, manifested in the exclusively wood-feeding lower termites, consists of three major steps that can be simplified as follows: (a) mechanical size reduction of the wood by the insect into very small particles of millimeter size in order to increase the surface area of the material by several orders of magnitude and allow access to its cellulose and hemicellulose components by other symbionts, the insect also serving as the bio-reactor vessel for the decomposition process; (b) assimilation of the small wood particles by eukaryotic single cell organisms comprised of flagellate protozoa (Parabasalia and Preaxostyla phyla) to hydrolyze cellulose and hemicellulose sugars into short chain fatty acids and acetate; and (c) fermentation of fatty acids and acetate into methane as well as the mineralization of nitrogen from the environment into ammonia by bacteria (mostly spirochaetes, but also bacteroides, firmicutes, proteobacteria, and others) and archaea (all types of methanogens), the ammonia being recycled back into the insect and the protists to supplement their nitrogen diet. This entire process is shown schematically in Figure 1. The insect bioreactor releases methane and carbon dioxide along with lignin-rich feces. It is estimated that the termite bioreactor is very efficient as it removes between $74 \%$ and $99 \%$ of cellulose and $65 \%$ to $87 \%$ of hemicellulose in the digested wood [16]. Thus, the digestion of lingo-cellulose in termite guts is used as a basic model for the industrial conversion of lingo-cellulosic biomass by microbes into methane biofuel and other bio-products. From a practical point of view, the lack of understanding of all the details of the intricate degradation of wood by lower termites and other insects, which may take 
decades, if ever, to fully elucidate, is not an impediment to developing a commercial process for the fermentation of wood into bio-methane fuel and a host of other co-products, as already mentioned. This situation is actually quite similar to the current status of the scientific elucidation of anaerobic digestion of agricultural wastes and other organics, which has been commercially available for over three decades at an industrial level, but which is still investigated in the laboratory to determine the interactive dynamics of the various microorganisms participating in it.

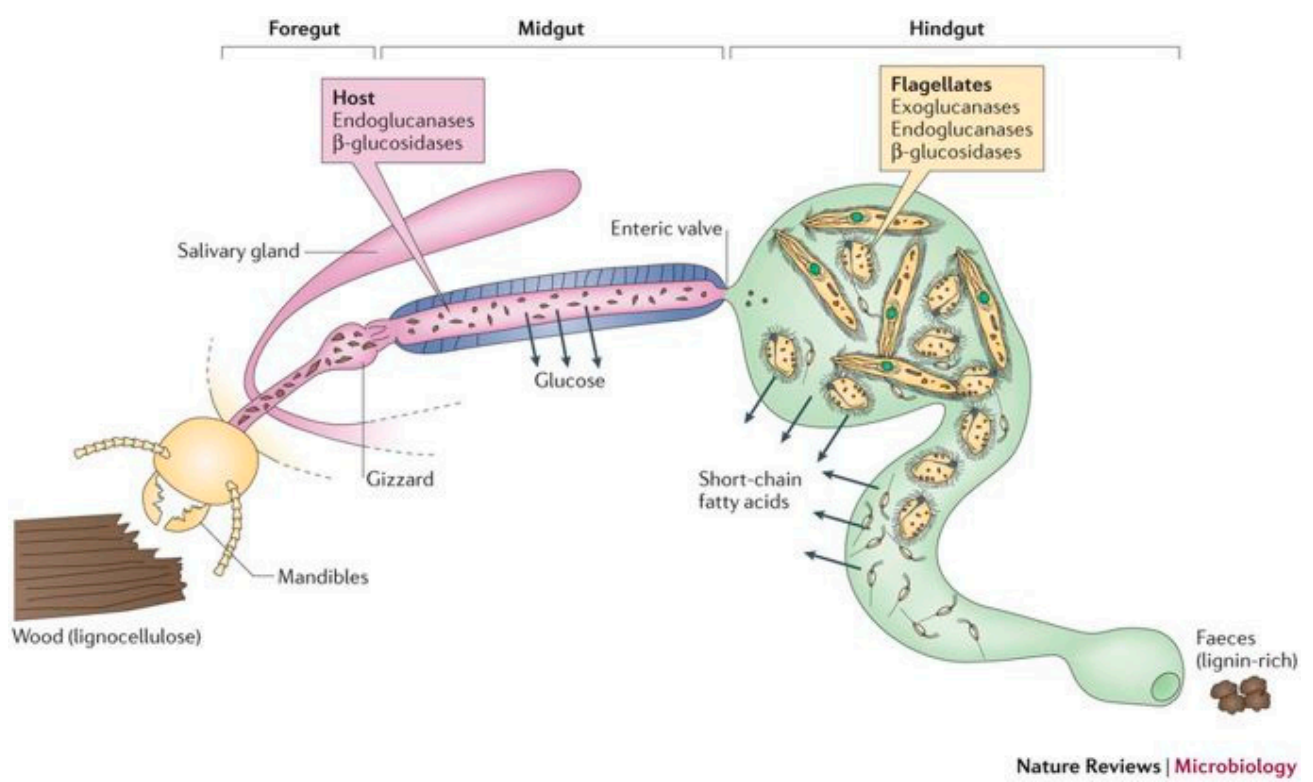

(a) The Dual Cellulolytic System of Lower Termites.

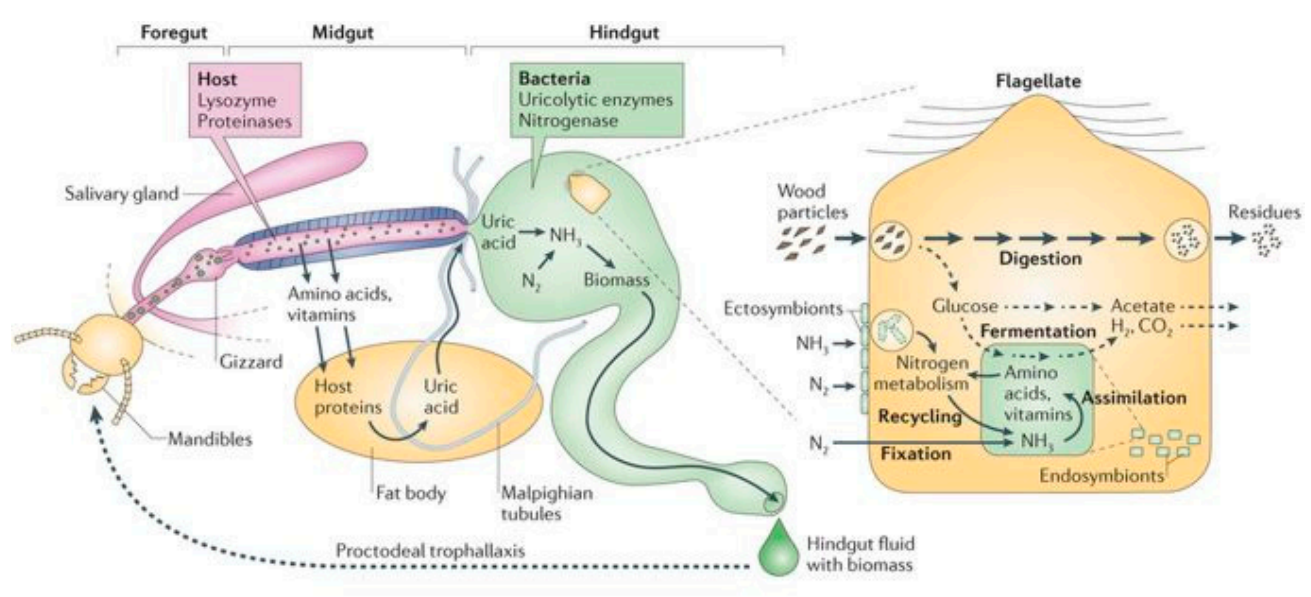

(b) The Nitrogen Cycling in Lower Termites.

Figure 1. Schematic of the wood fermentation process in lower termites comprised of (a) the breakdown of lignocellulose via mechanical and microbial processing and (b) the microbial mineralization of atmospheric nitrogen into ammonia and ultimately, proteins (reproduced from reference 15 with the permission of the publisher Springer Verlag).

\section{Practical Conversion of Wood to Bio-Methane}

The practical fermentation of wood wastes into bio-methane fuel has been developed based on the aforementioned process suggested by the behavior of termites combined with our experience in the commercialization of dry, thermophilic anaerobic digestion over the past thirty-five years $[17,18]$. The proposed "wood to methane" fermentation process, or W2M in its abbreviated form, follows the 
example of the termite process with certain important modifications and improvements in order to enhance conversion efficiency and maintain control of the process. A major improvement includes the co-fermentation or co-digestion of wood with a nitrogen-rich organic waste, namely, pig manure or poultry litter. The justification for selecting these manures will be explained shortly. Another improvement consists of the thermophilic operation of the bioreactor vs. the mesophilic operation in termites for reasons to be also discussed below. The W2M process is comprised of " $3+2$ " steps, i.e., five steps altogether, hence "W2M $3+2$ ". The initial "three" steps are as follows: (a) Maceration of wood into millimeter-size particles; (b) Homogenization and mostly aerobic, hyperthermophilic hydrolysis of the macerated wood with the manure relying primarily on thermophilic fungi; and (c) anaerobic digestion of the hydrolyzed materials by bacteria and archaea under dry thermophilic conditions to yield biogas, namely, a mixture of about $60 \%$ methane and $40 \%$ carbon dioxide. These three steps comprise the biological degradation of wood into a gaseous fuel. The last "two" steps are as follows: (d) Membrane separation of the biogas into 99\% + pure bio-methane fuel; and (e) sequestration of the carbon dioxide in the biogas to generate additional bio-methane fuel via its dry thermophilic anaerobic digestion, with a requisite amount of hydrogen to be generated by wind or solar driven power. All five steps will be discussed in detail in the remainder of this section.

The decomposition of wood in the gut of termites by flagellate protozoa requires, among others, a source of nitrogen that is used for the growth of these organisms as well as of that of the host insects. Wood serves as the source of carbon for all these organisms. The source of nitrogen in the termite bioreactor comes from food sources assimilated by the insects, but primarily comes from the atmosphere. Atmospheric nitrogen is fixed into ammonia by suitable bacteria that exist in the gut of the insect. In the large-scale implementation of the wood decomposition process, an external source of nitrogen must also be employed and a source of choice is either pig manure or poultry litter. It is well known that pig manure, which is about $10 \%$ total solids (TS), contains roughly $10 \%$ nitrogen in its dry state, i.e., $1 \%$ nitrogen in the wet state. This nitrogen in manure is mostly in the form of proteins and about $30 \%$ is in the form of ammonia. Poultry manure has similar nitrogen content, the main difference being that it is typically much drier at TS of about 70\% and therefore, would need dilution with water to $10 \%$ TS in order to be mixed properly with wood. Both pig manure and poultry litter also contain fats and some carbohydrates that make them an excellent source of methane on their own in an anaerobic digestion process, so long as there is a sufficient amount of carbon in the digested materials. The optimal ratio of carbon to nitrogen in a thermophilic anaerobic digestion process is about 20 to $1[19,20]$. Given that dry wood contains $50 \%$ carbon and dry pig manure or poultry litter contain about $10 \%$ nitrogen, we would need to co-digest $1 \mathrm{mt}$ of wood with $\frac{1}{4} \mathrm{mt}$ of dry pig manure or dry poultry litter or a mixture of the two in order to obtain the 20 to 1 ratio.

Assuming for practical purposes that the wood to be processed for fermentation has an $80 \%$ TS content and the pig manure/poultry litter has a $10 \%$ TS content, we would need to co-digest $2 \mathrm{mt}$ of pig manure ( $20 \mathrm{~kg}$ of $\mathrm{N}$ ) with $1 \mathrm{mt}$ of wood (400 kg of C). Incidentally, a major difference between poultry litter (broilers and turkeys) and pig manure is that the former is much drier in its natural state at about $75 \%$ TS, thereby requiring dilution with process wastewater to the $10 \%$ TS level. An additional advantage of co-digesting wood with either pig manure or poultry litter is that about $30 \%$ of the nitrogen in these manures is already mineralized in the form of ammonia. Ammonia is known to degrade wood by dissolving the lignin. Thus, during the hydrolysis step of the process and even during the fermentation, the ammonia present may accelerate the degradation of the macerated wood, such that the enzymes secreted from the fungi, bacteria, and archaea in the mix convert more cellulose and hemicellulose into methane and carbon dioxide.

The selection of the thermophilic operating temperature at $55^{\circ} \mathrm{C}$ has several advantages, but it also imposes a perceived restriction. The advantages include: (a) vast operating experience with dry thermophilic anaerobic digestion over the past three decades; (b) more than doubling of the rate of biogas production, which is due to the accelerated degradation of the feedstock materials in general and wood in particular; (c) reduction in the retention time in the digesters that reduces 
the size of the fermentation vessels and the associated costs; (d) sterilization of the digester effluent, thereby increasing its value as a fertilizer; and (e) synergistic operation with a dry, i.e., high in total solids, process to further reduce the volume of the digesters/bio-reactors and keep the cost lower. The perceived restriction is that the thermophilic operating temperature regime eliminates the flagellate protozoa operating in termites because all of them are mesophilic. The only eukaryotic organisms that operate in an elevated temperature above $45^{\circ} \mathrm{C}$ and are known to decompose wood are thermophilic fungi, which as it turns out, constitute a small fraction even among fungi, i.e., a few hundred species out of approximately 50,000 recorded species of fungi [21-23]. However, thermophilic fungi are ubiquitous in the environment as Figure 2 shows [23]. Thermophilic fungi are, in general, of wide interest due to their potential for the production of thermo-stable enzymes that can be used in industrial high-temperature processes.

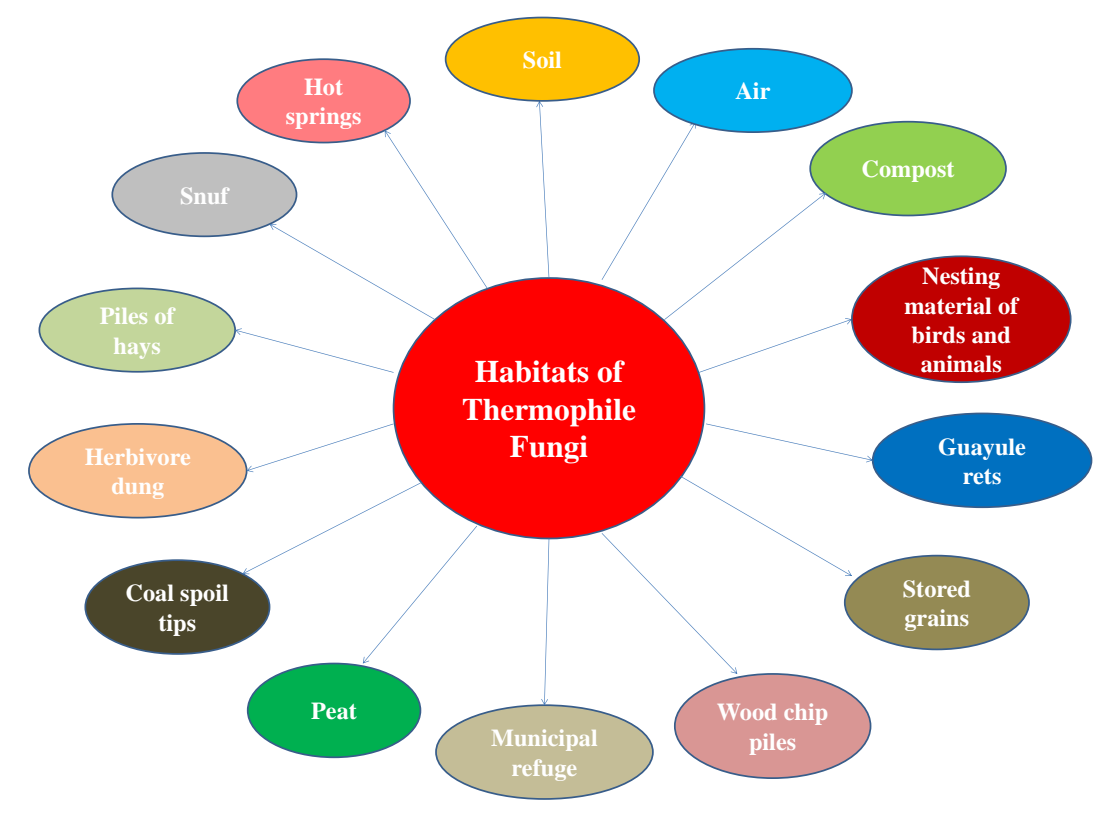

Figure 2. Some common habitats of thermophilic fungi.

The reliance on thermophilic fungi for the controlled co-digestion of wood with suitable animal manures is just such another industrial process described herein. Wood decomposition in wood chip piles, stored peat, and composting piles, which rise internally in temperature to hyperthermophilic levels of over $70{ }^{\circ} \mathrm{C}$, has been known for a long time to rely on a small number of thermophilic fungi, such as Humicola insolens (or Scytalidium Thermophilum under a recent but not universally accepted change in name) and Sporotrichum thermophile (or Myceliophthora thermophila under the new name), among others, to proceed very effectively under certain moisture (more than $50 \%$ water), temperature (over $45^{\circ} \mathrm{C}$ ), $\mathrm{pH}$ (range 4 to 8 , optimal around 6.8 ), and oxygen ( 0.7 to $1.05 \%$ for moderate growth) conditions to ferment cellulose and hemicellulose [21,23,24]. The cross-sectional distribution of temperature and oxygen in a mushroom compost pile shown in Figure 3 is indicative of the operational versatility of thermophilic fungi [23]. Moreover, the thermophilic fungus Humicola insolens has also been found to operate better under anaerobic or micro-aerobic conditions $[25,26]$. Thus, this fungus in particular and fungi of the Humicola sp. in general are expected to play a central role in wood hydrolysis and fermentation. It should be also noted that the relatively small number of known wood-digesting thermophilic fungi is not any smaller than the number of wood-decomposing flagellate protozoa found in the gut of termites [27]. 


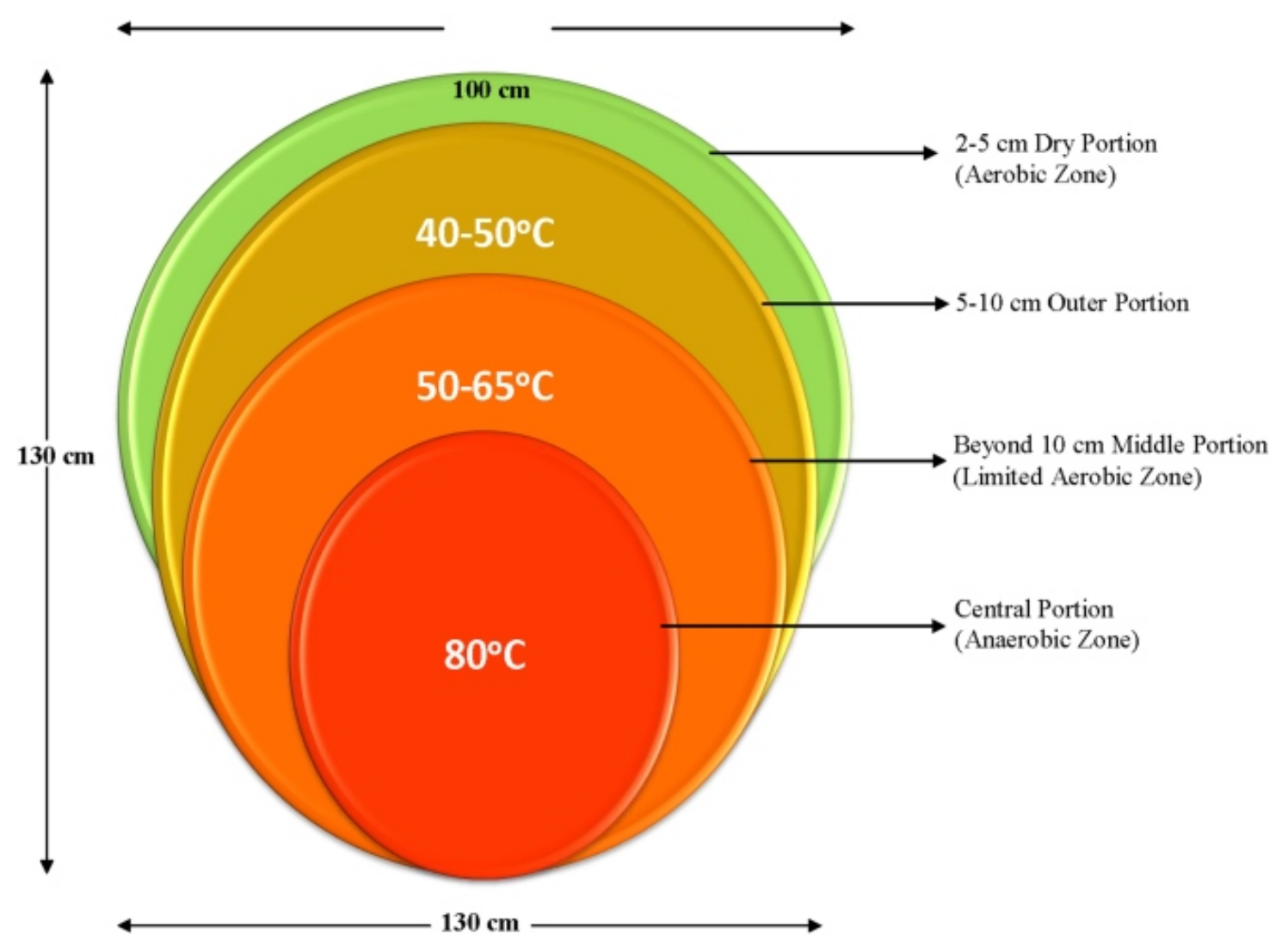

Figure 3. Sectional temperature and oxygen/air distributions in a mushroom compost pile attained within two days of piling the wet materials.

The aforementioned "W2M $3+2$ " process is shown schematically in Figure 4. Its first "3" steps mimic the steps employed by termites to digest wood. Thus, the breaking up of wood into small particles by the mandibles of the termites and the further comminuting of these particles in the gizzard of the insect are represented in our system by the wood maceration unit. It is well established that size reduction enhances the methane yield of biological wood fermentation by about $50 \%$ for a decrease in particle size from about $1 \mathrm{~cm}$ to about $1 \mathrm{~mm}[28,29]$. The wood maceration unit consists of a proprietary device employing hammer mills to break the wood and the wood fibers into small particles. This device, called "Molares", will accept wood chips 1-3 cm in size, obtained from wood processed through a commercial woodchipper and generate wood particles $0.2-2 \mathrm{~mm}$ in size. This wood maceration reduces cellulose crystallinity and facilitates immensely the exposure of cellulose and hemicellulose to the enzymes secreted by the thermophilic fungi as well as thermophilic bacteria such as thermophilic actinomycetes operating synergistically, although the fungi are the hydrolysis process drivers [30-32].

The macerated wood is then mixed with the manure in proportions as already described along with an amount of effluent from the fermenter exit in order to attain the typical 30\% TS content. This mixture is pumped into the hydrolysis vessel. A vertical mixing device inside the vessel ensures homogenization and facilitates the hydrolysis. The vessel is maintained at a hyperthermophilic operating condition of $70{ }^{\circ} \mathrm{C}$ via circulating hot water as necessary, while exterior-wall insulation ensures the temperature inside the vessel is the same throughout. The temperature is a process parameter and could be varied to optimize the hydrolysis of cellulose and hemicellulose. The introduced effluent is at about $10 \%$ of the rate of the incoming materials (wood and manure) and has as a major function the fast inoculation of the fresh materials with the functioning organisms (fungi, bacteria and archaea) in the digester and as a secondary function the adjustment of the water content in the hydrolysis vessel to the desirable $30 \% \mathrm{TS}$ content. If pig manure is used there will be no need to add any external water. If poultry litter If poultry manure is used as the co-digested material, there will be a need to add external wastewater such that 
the $30 \%$ TS is maintained. The retention time of the co-digested materials in the hydrolysis vessel varies between three and five days and is a process parameter. This retention time of up to five days is based on the observed wood and straw decomposition rates in composting as well as in studies of two-stage hyperthermophilic-thermophilic co-digestion studies, where the optimal solids retention time is found to be four days $[23,33]$. This step of the process is mostly aerobic and thermophilic fungi are mostly, but not exclusively, operating to hydrolyze particularly the wood component of the materials into simple compounds such as fatty acids. Small amounts of metered air as a processes parameter are injected into the hydrolysis vessel to optimize its operation, given that thermophilic fungi are aerobic but apparently function under reduced air conditions, as already indicated in the previous section and as the air distribution in Figure 3 confirms. Incidentally the tolerance of fungi to high temperatures and low oxygen levels could be the result of their symbiotic existence with viruses and bacteria that is just beginning to be recognized [34]. The sugars comprising the cellulose and hemicellulose are hydrolyzed into short chain fatty acids and acetate. The hyperthermophilic hydrolysis step of the "W2M $3+2$ "process constitutes a departure from the standard thermophilic hydrolysis step in the ECOCORP process dealing with non-wood substrates. It is in direct emulation of the typical compost pile temperature profile per Figure 3 and provides considerable advantages particularly in treating the wood portion of the substrates by enhancing and accelerating the normally recalcitrant acidification process of its sugars as well as of proteins and fats in the hydrolysis vessel [31-33]. Moreover, the hyperthermophilic operational temperature of the hydrolysis vessel is not detrimental to the functioning of the various microbes operating synergistically to hydrolyze the complex sugar substrate molecules into fatty acids as the example of the compost pile shown in Figure 3 would suggest and as lab-scale digester reactors have confirmed [33].

The hydrolyzed materials are then pumped into the fermentation vessel, which is maintained at $55^{\circ} \mathrm{C}$. The fermentation vessel is a plug flow reactor, where the materials move forward over a period of about 20 days, the typical retention time, which is also another process parameter. The roof of this reactor is made of an expandable membrane and serves as a temporary storage of the generated biogas $\left(60 \% \mathrm{CH}_{4}\right.$ and $\left.40 \% \mathrm{CO}_{2}\right)$. A longitudinal mixing device along the length of the reactor and a moving floor ensure that the materials in the reactor are continuously stirred and do not accumulate at the bottom. The thermophilic bacteria and archaea into the reactor consume the fatty acids and acetate and generate biogas that escapes out of the liquid effluent. Metered amounts of air are also introduced into the fermentation reactor to suppress the release of $\mathrm{H}_{2} \mathrm{~S}$ into the biogas, thereby resulting in the sulfur remaining in the liquid phase, i.e., reactor effluent, as sulfates and simultaneously support the functionality of certain thermophilic fungi operating better near anaerobic conditions to continue the degradation of the remaining cellulose and hemicellulose.

The next two steps in the process do not occur in the termite bioreactor, but are integral parts of the "W2M $3+2$ " process. The generated biogas is collected in the membrane roof of the fermentation vessel and from there, is directed to the biogas-upgrading unit, following the removal of water and the sulfur compounds in it. The biogas-upgrading unit consists of a standard commercially available membrane separation system [35]. A three-stage system will be used to recover over $99.8 \%$ of the methane in the biogas and produce $99 \%$ methane gas purity. Compared to other biogas upgrading systems, this system has a higher recovery rate and purity of methane, lower electricity use and requires an operational pressure of over 50 bar, which is ideal for the delivery of the generated bio-methane into a transmission natural gas pipeline. The fifth and final step in the process entails the sequestration of the carbon dioxide in the biogas and its utilization either as an industrial gas or to generate more bio-methane fuel. 


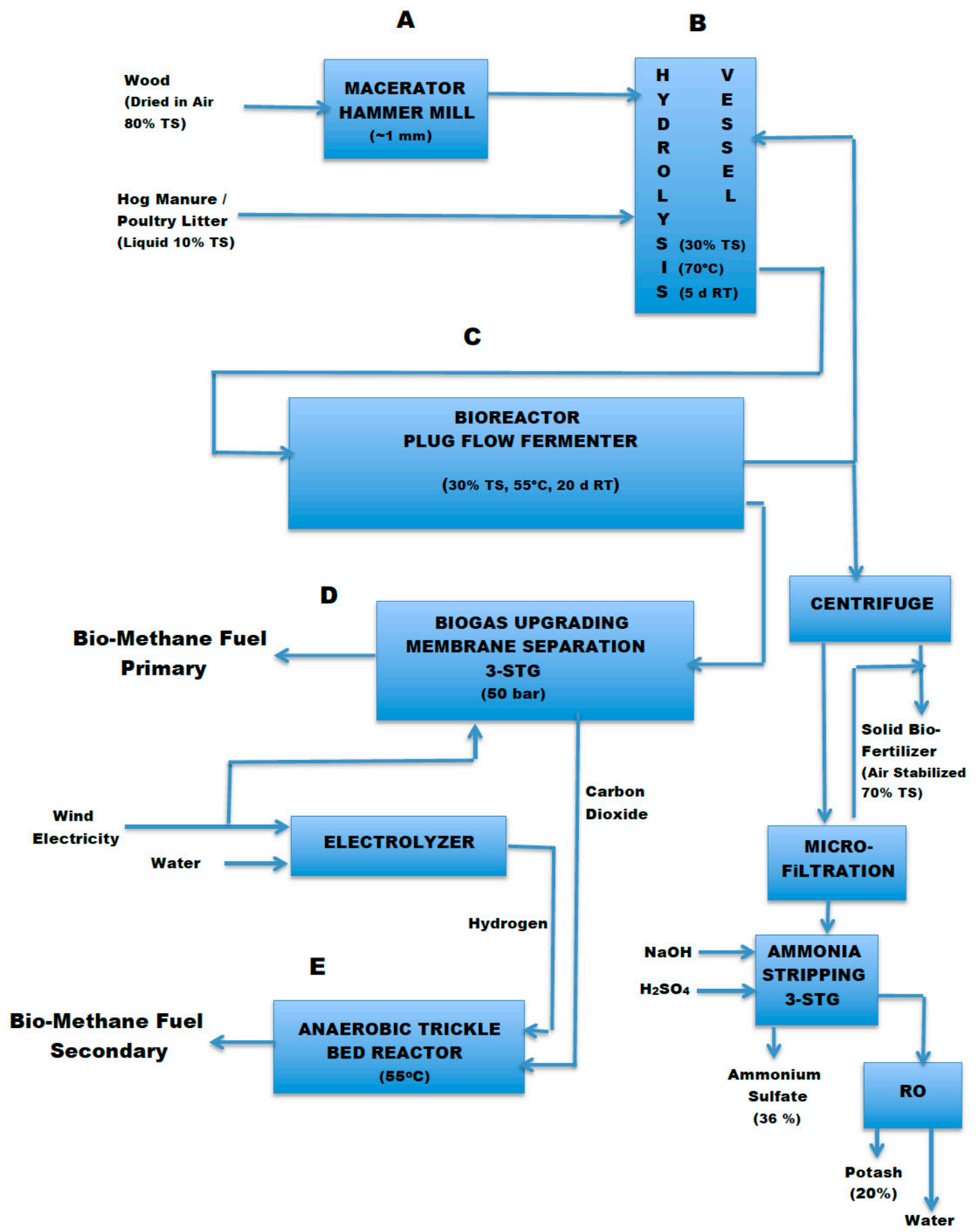

Figure 4. Diagram showing the five (" $3+2$ ") steps, A through E, of the wood to methane (W2M $3+2$ ) process derived from the termite model of wood decomposition and based on the dry thermophilic fermentation with hyperthermophilic hydrolysis of mechanically pretreated wood with the aid of thermophilic fungi, bacteria, and archaea and the use of wind (or solar) power as the energy source for the production of additional methane.

The exhaust from the membrane separation system, which consists of 95-99\% carbon dioxide, is then directed into a standard $\mathrm{CO}_{2}$ liquefaction unit to obtain pure carbon dioxide [36]. The liquid $\mathrm{CO}_{2}$ is then stored into cryogenic cylinders until it is picked up by industrial gas companies for sale to their customers. A more recent alternative use of the sequestered carbon dioxide in the exhaust of the membrane-upgrading system is to be used along with hydrogen in an anaerobic digester to 
produce bio-methane via a biological methanation process according to the reaction: $4 \mathrm{H}_{2}+\mathrm{CO}_{2}=\mathrm{CH}_{4}$ $+\mathrm{H}_{2} \mathrm{O}$ [37]. Hydrogen gas is produced from the electrolysis of water with wind or solar PV electricity. The hydrogen gas is then introduced into an anaerobic trickle bed reactor along with the sequestered carbon dioxide operating at $55{ }^{\circ} \mathrm{C}$. Hydrogenotrophic archaea predominated by Methanothermobacter thermautotrophicus convert almost $99 \%$ of the carbon dioxide into a higher than $98 \%$ methane gas output $[37,38]$. This technology has been developed as a means to store wind and solar power when the demand is below the supply, whereby the produced bio-methane serves as the storage medium [39]. One commercial size facility is operational in Denmark. The same technology can be used to convert the sequestered carbon dioxide into additional bio-methane fuel. One metric ton of carbon dioxide requires $182 \mathrm{~kg}$ of hydrogen to generate $363 \mathrm{~kg}$ of bio-methane. The required electricity to electrolyze water to obtain the hydrogen and also to operate the anaerobic digester for the production of the bio-methane is on the order of 10,000 kWh per mt of carbon dioxide, assuming an efficiency of $53.4 \mathrm{kWh}$ per $\mathrm{kg} \mathrm{H}_{2}$ or $4.8 \mathrm{kWh}$ per $\mathrm{m}^{3} \mathrm{H}_{2}$. The required wind power to generate this amount of electricity annually is on the order of $3.8 \mathrm{~kW}$ at $30 \%$ or higher wind capacity factor. The sizing of a functional system for the fermentation of wood into bio-methane will be examined in the next section of this document.

\section{System Design for the Conversion of Wood into Bio-Methane}

The design and sizing of an industrial type standardized modular system for the fermentation of wood into bio-methane incorporating the five process steps described in the previous section is the basis of the design of the standardized commercially available modular biogas plant unit operating under dry, thermophilic conditions that has been developed by our team $[40,41]$. This unit consists of two plug-flow reactors made of precast concrete with a flexible double-membrane roof, each having a gross volume of about $3500 \mathrm{~m}^{3}$ comprised of $1500 \mathrm{~m}^{3}$ for the liquid and $2000 \mathrm{~m}^{3}$ for the gaseous components. Each plug flow reactor has its own hydrolysis vessel comprised of a vertical steel vessel with a gross volume of $350 \mathrm{~m}^{3}$ sized for this application. A slowly rotating longitudinal mixing device with paddles made of steel is installed in each plug-flow reactor along with a moving steel floor. A vertical mixing device also slowly rotating and made of steel is part of each hydrolysis vessel. The hyperthermophilic operating temperature of $70^{\circ} \mathrm{C}$ is maintained in the hydrolysis vessels and a thermophilic temperature of $55^{\circ} \mathrm{C}$ is maintained in the plug-flow reactors via hot water circulation. Two hammer mill-type solids macerators rated at $1 \mathrm{mt}$ per hour each are part of the system, each macerator feeding the respective hydrolysis vessel. Positive displacement pumps are employed to move the nominally $30 \%$ TS feedstock materials between the components of the system. The biogas collected in the membrane roofs of both reactors is directed into and upgraded to bio-methane by a three-stage membrane separation system rated nominally at $1000 \mathrm{~m}^{3}$ per hour. A carbon dioxide liquefaction system rated at $20 \mathrm{mt}$ per day is employed to sequester the carbon dioxide in the biogas. The liquid effluent from the two reactors is centrifuged via two high speed units rated at $5 \mathrm{mt}$ per $\mathrm{h}$ each. The solid fraction is dried via aeration over a period of two weeks to yield stabilized soil conditioner rich in phosphate and humic substances. The liquid fraction is first subjected to micro-filtration so that any remaining suspended solids are removed and returned to the solid fraction and is then subjected to a three-stage ammonia stripping process to yield commercial grade ammonium sulfate bio-fertilizer. The rejected liquid rich in potassium is subjected to evaporation to yield potassium concentrate as a bio-fertilizer. A processing building with a $1000-\mathrm{m}^{2}$ footprint contains the plant controls as well as the aforementioned processing equipment associated with the operation of the plant, excluding the hydrolysis vessels, plug-flow reactors, and biogas-upgrading units. The feedstock materials are kept in fully enclosed spaces and are transported into the processing building as needed. The operation of the plant is continuous with a nominal operating capability of $95 \%$ of the time.

Based on the physical size of commercially available plug-flow digesters and the physical properties of the wood and manure substrates, the standardized wood fermentation unit would process annually $12,000 \mathrm{mt}$ of wood wastes at $80 \%$ TS and $24,000 \mathrm{mt}$ of pig manure at $10 \%$ TS. If poultry litter is used at nominally $75 \% \mathrm{TS}, 3200 \mathrm{mt}$ of it will be diluted with $20,800 \mathrm{mt}$ of process wastewater to 
$10 \%$ TS. The generated annually amount of biogas would be 7.5 million $\mathrm{m}^{3}$, of which bio-methane would be 4.5 million $\mathrm{Nm}^{3}$ and carbon dioxide 3.0 million $\mathrm{Nm}^{3}$. It is assumed that $90 \%$ of the cellulose and $80 \%$ of the hemicellulose in the wood are hydrolyzed. A summary of the material inputs and outputs of the standardized wood fermentation unit is given in Table 1. This mass balance is based on the aforementioned assumed hydrolysis of wood in conjunction with production rates of similar operating conditions in biogas plants. The three-stage membrane separation system for the upgrading of the biogas will capture $99.6 \%$ of the available methane. The energy content in the bio-methane is $45,000,000 \mathrm{kWh}\left(10 \mathrm{kWh}\right.$ per $\left.\mathrm{Nm}^{3}\right)$. The energy content in the processed wood is on the order of $55,000,000 \mathrm{kWh}(5750 \mathrm{kWh}$ per dry $\mathrm{mt})$ and in the processes manure is on the order of $13,000,000 \mathrm{kWh}$ for a total of $68,000,000 \mathrm{kWh}$. Thus, about $66 \%$ of the total energy contained in the wood and in the manure is converted into bio-methane.

Table 1. Mass balance of the nominal wood fermentation to bio-methane plant unit.

\begin{tabular}{|c|c|c|}
\hline Inputs: & $\begin{array}{l}\text { Wood Wastes Air Dried } \\
\text { Pig Manure or diluted Poultry Litter } \\
\text { Flux (Reactor Effluent) } \\
\text { Sulfuric Acid (96\%); Sodium Hydroxide (50\%) }\end{array}$ & $\begin{array}{l}12,000 \mathrm{mt} / \mathrm{yr} \text { at } 80 \% \mathrm{TS} \\
24,000 \mathrm{mt} / \mathrm{yr} \text { at } 10 \% \text { TS } \\
4000 \mathrm{mt} / \mathrm{yr} \\
900 \mathrm{mt} / \mathrm{yr} ; 200 \mathrm{mt} / \mathrm{yr}\end{array}$ \\
\hline Outputs: & $\begin{array}{l}\text { Wet Biogas } \\
\text { Bio-Methane Dry-Primary } \\
\text { Carbon Dioxide Dry } \\
\text { Hydrogen via Electrolysis } \\
\text { Bio-Methane Dry-Secondary } \\
\text { Flux } \\
\text { Solid Fraction of Centrate } \\
\text { Solid Bio-Fertilizer } 70 \% \text { TS } \\
\text { Liquid Fraction of Centrate } \\
\text { Ammonium Sulfate }(36 \%) \\
\text { Potassium Concentrate }(12.5 \%) \\
\text { Recyclable Industrial Water }\end{array}$ & $\begin{array}{l}10,988 \mathrm{mt} \\
4.5 \mathrm{million} \mathrm{Nm}^{3} \text { or } 3226 \mathrm{mt} \\
3.0 \text { million } \mathrm{Nm}^{3} \text { or } 5931 \mathrm{mt} \\
12.4 \text { million } \mathrm{Nm}^{3} \text { or } 1116 \mathrm{mt} \\
3.1 \mathrm{million} \mathrm{Nm}^{3} \text { or } 2226 \mathrm{mt} \\
4000 \mathrm{mt} \\
11,715 \mathrm{mt} \\
3347 \mathrm{mt} \\
13,297 \mathrm{mt} \\
3250 \mathrm{mt} \\
1600 \mathrm{mt} \\
9347 \mathrm{mt}\end{array}$ \\
\hline
\end{tabular}

The amount of carbon dioxide produced as an industrial gas will be just short of $6000 \mathrm{mt} / \mathrm{yr}$. As we have already discussed, this carbon dioxide will be used in conjunction with water electrolysis and additional anaerobic digestion to produce more bio-methane. The stoichiometric amount of bio-methane to be produced is at a rate of $363 \mathrm{~kg}$ per $\mathrm{mt}$ of $\mathrm{CO}_{2}$. At a $\mathrm{CO}_{2}$ capture efficiency of $98 \%$, some $2226 \mathrm{mt} / \mathrm{yr}$ of additional bio-methane output would be obtained or about 3.1 million $\mathrm{m}^{3}$ per year. This amount is just $69 \%$ of the bio-methane produced from the direct fermentation of the wood and is obviously quite significant. However, a large amount of wind power would be required on the order of $25 \mathrm{MW}$ for the standardized wood fermentation plant unit, including the electricity use for the primary bio-methane production, which is about $10 \%$ of the total. A wind installation of $25 \mathrm{MW}$ collocated or accessible via power lines would be required.

A related benefit associated with this conversion of waste wood and animal manures into bio-methane fuel and bio-fertilizers is the reduction in the emissions of greenhouse gases. As we have already noted, some $6000 \mathrm{mt}$ of carbon dioxide will be sequestered in the standardized plant and be converted to additional bio-methane. The electricity use for the primary and secondary production of the bio-methane and the bio-fertilizers would be derived from renewable wind power and would have a near zero carbon footprint. Likewise, the heat requirement for the process will be supplied by the generated biogas itself and will also have a near zero carbon emissions footprint. Of the feedstock materials, wood as a renewable resource would also have a near zero carbon footprint. The utilization of the animal manures with an energy content of 13,000,000 $\mathrm{kWh}$, however, would generate a negative carbon footprint. This can be estimated on the basis of the energy content in the manures and the average carbon footprint in fossil fuels that the bio-methane would replace. The average carbon footprint of fossil fuels themselves in carbon dioxide emissions ranges from a high 
of $0.325 \mathrm{~kg} / \mathrm{kWh}$ for coal, to $0.248 \mathrm{~kg} / \mathrm{kWh}$ average for diesel $/$ gasoline to $0.181 \mathrm{~kg} / \mathrm{kWh}$ for natural gas. The resulting annual negative footprint of the utilized manure would range from a high of $4225 \mathrm{mt}$ as a coal replacement to $3224 \mathrm{mt}$ as a diesel/gasoline replacement to $2353 \mathrm{mt}$ as a natural gas replacement. Thus, the nominal reduction in greenhouse gas emissions from the operation of the standardized plant would be conservatively around 10,000 $\mathrm{mt}$ per year.

\section{The US Potential of Bio-Methane Production from Wood Wastes}

As it was analyzed in Section 2, the annual production of wood wastes in the US can range from a minimum of 100 million dry $\mathrm{mt}$, representing just the collection of the tree mortalities, to a potential maximum of 400 million dry $\mathrm{mt}$ with proper forest management including tree thinning and collection of the mortalities. The annual production of collectable pig manure and of poultry litter in the US is on the order of 130 million dry $\mathrm{mt}$ [42]. Based on the required carbon to nitrogen ratio, about $74 \%$ of it would be co-digested with the maximum available wood waste as shown in Table 2. Consequently, over 41,500 modular fermentation units would be required to process these wood wastes along with manure into bio-methane. The produced "primary" bio-methane would amount to 187 billion $\mathrm{m}^{3 /} \mathrm{yr}$ (6.4 quads annually). In addition, almost 250 million $\mathrm{mt}$ of carbon dioxide would be sequestered for conversion to additional bio-methane with the input of wind power. The "secondary" bio-methane would amount to 129 billion $\mathrm{m}^{3} / \mathrm{yr}$ (4.4 quads annually).

Table 2. Potential for annual production of bio-methane in the US from the co-fermentation of wood wastes with currently available pig manure and poultry litter.

\begin{tabular}{|c|c|}
\hline Materials & Amounts \\
\hline Wood Wastes Dry & $400,000,000 \mathrm{mt}$ \\
\hline Hog Manure and Poultry Litter Dry & $100,000,000 \mathrm{mt}$ \\
\hline Number of Modular Fermentation Units Required & 41,666 \\
\hline Primary Bio-Methane Production ( 4.5 million $\mathrm{m}^{3}$ per unit) & 187.47 billion $\mathrm{m}^{3} / 6.4$ quads \\
\hline Sequestered Carbon Dioxide & $247,121,000 \mathrm{mt}$ \\
\hline Secondary Bio-Methane Production (3.1 million $\mathrm{m}^{3}$ per unit) * & 129.14 billion $\mathrm{m}^{3} / 4.4$ quads \\
\hline Wind Power for Secondary Bio-Methane Production (25 MW per unit) & $1050 \mathrm{GW}$ \\
\hline Total Bio-Methane Production & 316.61 billion $\mathrm{m}^{3} / 10.8$ quads \\
\hline
\end{tabular}

The required wind power would be on the order of $1000 \mathrm{GW}$. This wind power is less than $10 \%$ of the wind power potential of the US estimated at 12,000 GW on-shore at $100 \mathrm{~m}$ turbine height and at $30 \%$ or higher capacity factor and over $2000 \mathrm{GW}$ off-shore [43]. We conclude then that the dry, thermophilic co-digestion of wood wastes along with hog manure and poultry litter would generate over 316 billion $\mathrm{m}^{3}$ of renewable natural gas or over 11 trillion standard cubic feet. This amount of natural gas would represent about 35\% of the current production of fossil natural gas in the US [44]. Lastly, this bio-methane production would represent over 10 quads of energy annually or almost $11 \%$ of the energy consumption of the country. Consequently, the dry, thermophilic co-digestion of wood wastes along with hog manure and poultry litter has the potential to become a very significant source of a renewable fuel in the form of bio-methane.

The cost associated with the development of the standardized "W2M $3+2$ " fermentation unit will consist of the main anaerobic digestion unit to produce biogas, the upgrading system of biogas to primary bio-methane, the sequestration of the carbon dioxide system, the hydrogen production electrolysis unit, the microbial conversion of the carbon dioxide and hydrogen into the secondary bio-methane system, and the wind power installation. The present cost of the entire "W2M" unit is summarized in Table 3 and is based on currently available best values of the various major components. 
Economies of scale, particularly for wind power and water electrolysis systems, will drive down the associated cost as is also shown in Table $3[45,46]$. A conservative reduction in total cost by a factor of two to three is, thus, a realistic projection [47]. The levelized cost of bio-methane production over a 20 -year plant life and 20\% O\&M is reduced also by a factor of three, as shown in Table 3 . By comparison, the current price of natural gas in the US is 0.075 USD per $\mathrm{m}^{3}$ as a commodity, although this price increases to about 0.450 USD per $\mathrm{m}^{3}$ as an advanced transportation fuel, if the renewable fuel standard (RFS) and the low carbon fuel standard (LCFS) pricing are included.

Table 3. Present capital cost of the standardized "W2M $3+2$ " unit and future capital cost due to economies of scale and increased efficiencies.

\begin{tabular}{|c|c|c|}
\hline Component & Present Cost & Future Cost \\
\hline Basic Plug-Flow Digester System w/pre-and post-processing of bio-fertilizers & $\$ 5,000,000$ & $\$ 4,000,000$ \\
\hline Biogas Upgrading System $1000 \mathrm{~m}^{3} / \mathrm{hr}-3 \mathrm{stg}$ memb. & $\$ 1,500,000$ & $\$ 1,000,000$ \\
\hline Water Elecrolyser $7.5 \mathrm{MW}-\mathrm{AEC}\left(4.8 \mathrm{kWh} / \mathrm{m}^{3} \mathrm{H} 2\right)$ & $\$ 18,000,000$ & \\
\hline $5.5 \mathrm{MW}-\mathrm{SOEC}\left(3.8 \mathrm{kWh} / \mathrm{m}^{3} \mathrm{H} 2\right)$ & & $\$ 5,500,000$ \\
\hline Wind Power 25 MW (present w/AEC electrolyser) & $\$ 35,000,000$ & \\
\hline $20 \mathrm{MW}$ (future w/SOEC electrolyser) & & $\$ 10,000,000$ \\
\hline Total & $\$ 59,500,000$ & $\$ 20,500,000$ \\
\hline Levelized Cost of Bio-Methane Production & $\$ 0.476 / \mathrm{m}^{3}$ & $\$ 0.137 / \mathrm{m}^{3}$ \\
\hline
\end{tabular}

The production of the 316 billion $\mathrm{m}^{3} / \mathrm{yr}$ of bio-methane as a transportation fuel represents the equivalent of over 350 billion liters gasoline. This amount of renewable bio-methane transportation fuel is three times the amount prescribed by the RFS (Renewable Fuel Standard) legislation in 2005 and represents 70\% of the gasoline used in the US in 2018 [48]. We may also note that the utilization of the remaining 30 million $\mathrm{mt} / \mathrm{yr}$ hog manure and poultry litter along with 412 million $\mathrm{mt} / \mathrm{yr}$ of non-wood-based agricultural residues can yield 6.7 quads of primary bio-methane, 4.6 quads of secondary bio-methane, and will require an additional $1100 \mathrm{GW}$ of wind power [49]. The generated bio-methane from these non-wood wastes would be 11.3 quads of energy per annum, with a volume of 331 billion $\mathrm{Nm}^{3}$ per annum and would represent $37 \%$ of the current natural gas production in the US. Altogether then, the conversion of collectable organic wastes to bio-methane, including wood wastes and utilizing wind power for converting carbon dioxide to additional bio-methane, can supply 22 quads annually or $22 \%$ of the annual use of energy in the United States.

The current investment cost for the 41,000 "W2M $3+2$ " plants is on the order of 2.45 trillion USD with a future investment cost reduced to 840 billion USD over a period of 20 years due to economies of scale as well as advancements in technology. An annual investment starting at 120 billion USD to be reduced ultimately to 40 billion USD is well within the means of the US economy to develop these facilities. The levelized cost of the produced renewable natural gas can be justified at the present time if the fuel is used as a transportation fuel under the prevailing renewable fuel standard as well as the low carbon fuel standard. This is a very large investment essentially in infrastructure of the country and would require a public-private partnership in order to be carried out. The plants would be developed, constructed, and be operated by the private sector. The federal and state governments would provide financial support in terms of grants and loans up to $50 \%$ of the cost, while the private sector would raise the remaining $50 \%$ of the cost. The federal government could also support the renewable fuel pricing as it is already doing through existing and new standards that would need to include the price of avoided carbon emissions. Co-operation between the state governments and the federal government would be also necessary in order to facilitate and streamline the siting and permitting of the plants. 
Lastly, the implementation of appropriate forest management practices should be carried out by the federal and state agencies along with private owners in order to ensure that the waste wood fuel is harvested and available for use. This effort represents a most effective undertaking to utilize a large, but underutilized biomass resource to contribute along with other renewable energy sources to the so-called "de-carbonization" of the economy.

\section{Conclusions}

The US potential of biomass to be derived from wood wastes of forested lands is quite large, if proper forested land management practices are put in place over a period of 20 years. This wood wastes source can be converted to bio-methane in combination with about three-quarters of the current annual generation of rich in nitrogen animal manures from hogs and poultry via anaerobic digestion by emulating the steps involved in the naturally occurring wood decomposition by lower termites. Moreover, the carbon dioxide sequestered in the upgrading of the produced biogas can be converted to secondary bio-methane via fermentation with hydrogen derived from the electrolysis of water powered with wind power, which is also abundant in the US. The conversion process includes the fine maceration of wood, employs commercially available anaerobic digestion plug-flow bioreactor technology, and relies on thermophilic fungi among others as the key wood-decomposing organisms. Over 41,000 standardized "W2M $3+2$ " modular plant units, obviously concentrated over several hundred sites across the country depending on the location of the feedstock wastes, wind power, and electricity and natural gas transmission infrastructure, will be required to process annually the available wood along with the requisite amount of hog manure and poultry litter. Some $11 \%$ of the present US energy use can be supplied annually from these resources in a circular economy, whereby wastes from the advanced economy are reused with the inclusion of solar energy in the form of biomass and wind. In order for the generated bio-methane to be cost competitive, it must be deployed as an advanced renewable transportation fuel to replace fossil gasoline and diesel fuels as part of augmented renewable fuel and low carbon fuel standards across the country. The required large investment should occur as part of the 21st century infrastructure development in the country and would require an appropriate public-private partnership in order to be realized.

Funding: The author has not received any external funding.

Acknowledgments: The author would like to acknowledge discussions and the evolution of thermophilic anaerobic digestion with several ECOCORP team members over a period of time, including Frederick A. Hoover, PE in the US, Christian A. Kaendler in Germany, and Ing. Jan Driegen in The Netherlands. However, the final responsibility of this work rests with its author.

Conflicts of Interest: The author declares no conflict of interest.

\section{Abbreviations}

$\begin{array}{ll}\mathrm{mt} & \text { Metric tons } \\ \mathrm{mt} / \mathrm{yr} & \text { Metric tons per year } \\ \mathrm{m}^{3} & \text { Cubic meters: expressed at normal temperature }\left(0{ }^{\circ} \mathrm{C}\right) \text { and pressure }(1 \mathrm{~atm}) \\ \mathrm{m}^{3} / \mathrm{yr} & \text { Cubic meters per year } \\ \text { Quad } & \text { Energy unit equal to } 1 \text { quadrillion Btu or } 1.055 \times 10^{18} \text { Joule } \\ \text { RNG } & \text { Renewable Natural Gas } \\ \mathrm{TS} & \text { Total Solids } \\ \text { VS } & \text { Volatile Solids }\end{array}$

\section{References}

1. Hickey, M.; King, C. The Cambridge Illustrated Glossary of Botanical Terms; Cambridge University Press: Cambridge, UK, 2001.

2. Barette, J.-P.; Hazard, C.; Mayer, J. Mémotech Bois et Matériaux Associés; Editions Casteilla: Paris, French, 1996.

3. Boerjan, W.; Ralph, J.; Baucher, M. Lignin Biosynthesis. Ann. Rev. Plant Biol. 2003, 54, 519-549. [CrossRef] 
4. Agneta, M.; Kuckurek, M.J.; Pyiatte, J.A.; Wright, E.E. Kraft Pulping. A Compilation of Notes; TAPPI Press: Atlanta, GA, USA, 1993.

5. Fiebach, K.; Grimm, D. Resins, Natural. In Ulmann's Encyclopedia of Industrial Chemistry; Wiley-VCH: Weinheim, Germany, 2000.

6. White, R.H. Wood Handbook - Wood as an Engineering Material; General Technical Report FPL-GTR-113; U.S. Department of Agriculture, Forest Service, Forest Products Laboratory: Madison, WI, USA, 1999.

7. Sterrett, F.S. Alternative Fuels and the Environment; CRC Press: Boca Raton, FL, USA, 1994.

8. Food and Agriculture Organization of the United Nations. Global Forest Resources Assessment; Food and Agriculture Organization of the United Nations: Rome, Italy, 2020.

9. Nimz, H.H.; Schmitt, U.; Schwab, E.; Wittmann, O.; Wolf, F. Wood. In Ullmann's Encyclopedia of Industrial Chemistry; Wiley-VCH: Weinheim, Germany, 2005.

10. U.S. Department of Agriculture-Forrest Service. U.S. Forrest Facts and Historical Trends; U.S. Department of Agriculture-Forrest Service: Washington, DC, USA, 2020.

11. U.S. Energy Information Administration. Biomass Explained-Wood and Wood Waste; U.S. Energy Information Administration: Washington, DC, USA, 2019.

12. Baumgras, J.E. Biomass Yields from Allegheny Hardwood Thinning; Forest Service Research Paper NE-466; US Department of Agriculture: Broomhall, PA, USA, 1980.

13. Graham, R.T.; Harvey, A.E.; Jain, T.B.; Tonn, J.R. The Effects of Thinning and Similar Stand Treatments in Fire Behavior in Western Forests; Report PNW-GTR-463; U. S. Department of Agriculture-Forest Service and U.S. Department of the Interior-Bureau of Land Management: Portland, OR, USA, 1999.

14. Damien, A. La Biomasse Energie-Definitions, Resources et Modes de Transformation, 2nd ed.; Dunod: Paris, French, 2013.

15. Brune, A. Symbiotic Digestion of Lignocellulose in Termite Guts. Nat. Rev. Microbiol. 2014, 12, 168-180. [CrossRef]

16. Bignell, D.E.; Eggerton, P. Termites: Evolution, Sociality, Symbioses, Ecology; Abe, T., Bignell, D.E., Higashi, M., Eds.; Kluwer Academic Publishers: Dordrecht, The Netherlands; New York, NY, USA, 2000; pp. 363-387.

17. Ingersoll, J.G. ECOCORP Business Brochure; ECOCORP, Inc.: Arlington, VA, USA, 2019.

18. Graf, F.; Bajor, S. Biogas: Erzeugung, Aufbereitung, Einspeisung; Oldenbourg Industrieverlang, GmbH: Munchen, Germany, 2011.

19. Marchaim, U. Biogas Processes for Sustainable Development; FAO: Rome, Italy, 1992.

20. Deublein, D.; Steinhauser, A. Biogas from Wastes and Renewable Resources; Wiley-VCH: Weinheim, Germany, 2008.

21. Cooney, D.G.; Emerson, R. Thermophilic Fungi-An Account of their Biology, Activities and Classification; W.H. Freeman and Company: San Francisco, CA, USA; London, UK, 1964.

22. Maheshwan, R.; Bharadwaj, G.; Bhat, M.K. Thermophilic Fungi: Their Physiology and Enzymes. Microbiol. Mol. Biol. Rev. 2000, 64, 461-488. [CrossRef] [PubMed]

23. Salar, R.K. Thermophilic Fungi: Basic Concepts and Biotechnological Applications; CRC Press-Francis \& Taylor Group: Boca Raton, FL, USA; London, UK; New York, NY, USA, 2014.

24. Waksman, S.A.; Umbrett, W.W.; Cordon, C.T. Thermophylic Actinomycetes and Fungi in Soils and in Composts. Soil Sci. 1939, 47, 37-61. [CrossRef]

25. Henssen, A. Über die Bedeutung der thermophilen Mikroorganismen fur die Zersetzung des Stallmistes. Arch. Mikrobiol. 1957, 27, 63-81. [CrossRef] [PubMed]

26. Emerson, R. The Fungi: An Advanced Treatise, Vol. 3; Ainsworth, G.C., Sussman, A.S., Eds.; Academic Press Inc.: New York, NY, USA, 1968; pp. 105-128.

27. Schlegel, H.G. General Microbiology, 7th ed.; Kogut, M., Translator; originally published in German as Allgemeine Mikrobiologie; Cambridge University Press: Cambridge, UK, 1997.

28. Tsao, G.T. Pre-/Post Treatment. In Anaerobic Digestion of Biomass; Chynoweth, D.P., Isaacson, R., Eds.; Elsevier Applied Science: London, UK; New York, NY, USA, 1987; pp. 91-107.

29. Das, A.; Mondal, C.; Roy, S. Pretreatment Methods of Ligno-Cellulosic Biomass: A Review. J. Eng. Sci. Technol. Rev. 2015, 8, 141-165. [CrossRef]

30. Miehe, H. Die Wärmebildung von Reinkulturen im Hinblick auf die Ätiologie der Selbsterhitzung pflanzlicher Stoffe. Arch. Miktobol. 1930, 1, 78-118. 
31. Millet, M.A.; Baker, A.J.; Scatter, L.D. Physical and Chemicl Pretreatment for enhancing Celluose Saccharification. Biotech. Bioeng. Symp. 1976, 6, 125-153.

32. Sun, Y.; Chenh, J. Hydrolysis of Lignocellulosic Materials for Ethanol Production: A review. Bioresour. Technol. 2002, 83, 1-11. [CrossRef]

33. Wang, F.; Hidaka, T.; Tsuno, H.; Tsubota, J. Co-digestion of Polyactide and Kitchen Garbage in Huperthermophilic and Thermophilic Continuous Anaerobic Process. Bioresour. Technol. 2012, 112, 67-74. [CrossRef] [PubMed]

34. Marques, L.M.; Redman, R.S.; Rodriguez, R.J.; Roossnick, M.J. A Virus in a Fungus in a Plant: Three Way Symbiosis Required for Thermal Tolerance. Science 2007, 315, 513-515, See also: Sheldrake M (2020), Entangled Life - How Fungi Make our Worlds, Change our Minds \& Shape our Futures, p 17, Random House, NY. [CrossRef] [PubMed]

35. XEBEC Adsorption USA. Xebec BGX Biogas Brochure; XEBEC Adsorption USA, Inc.: Houston, TX, USA, 2015.

36. The Wittemann Company LLC (Union Engineering). Available online: www.wittemann.com (accessed on 14 August 2020).

37. Strubing, D.; Huben, B.; Lebuhn, M.; Drewes, J.E. High Performance Biological Methanation in a Thermophilic Anaerobic Trickle Bed Reactor. Bioresour. Technol. 2017, 245, 1176-1183. [CrossRef] [PubMed]

38. Kougias, P.; Treu, L.; Benavente, D.P.; Boe, K.; Campanaro, S.; Angelidaki, I. Ex-situ Biogas Upgrading and Enhancement in Different Reactor Systems. Bioresour. Technol. 2017, 255, 429-437. [CrossRef] [PubMed]

39. Elecrochaea G.m.b.H., 82152 Planegg, Bavaria, Germany. Available online: www.electrochaea.com (accessed on 14 August 2020).

40. ECOCORP. The Standardized Modular Industrial Type Biogas Plant Unit. Available online: http://www. ecocorp.com (accessed on 14 August 2020).

41. Ingersoll, J.G. Bio-Methane, Xlibris Corporation. 2010. Available online: www.xlibris.com (accessed on 14 August 2020).

42. Ingersoll, J.G. ibid. 2010. Available online: www.xlibris.com (accessed on 14 August 2020).

43. US DOE Wind Energy Technologies Office. A 2009 Technical Wind Resource Assessment estimated that the land-based wind energy potential for the contiguous United States is 10,500 GW at $80 \mathrm{~m}$ and 12,000 GW at $100 \mathrm{~m}$ heights, assuming a capacity factor of at least 30\%. A 2016 Assessment of Offshore Wind Resources refined previous assessments by first calculating the gross resource potential within 200 nautical miles of shore using 100-meter hub heights as 10,800 GW and then applied technical, environmental, and competing-use exclusions to find a technical resource potential of $2058 \mathrm{GW}$ and 7203 terawatt-hours per year of generation-nearly double the nation's annual electricity use. In Wind Resource Assessment and Characterization; US DOE Wind Energy Technologies Office: Washington, DC, USA. Available online: https: //www.energy.gov/eere/wind/wind-resource-assessment-and-characterization (accessed on 14 August 2020).

44. The Natural gas Production in the US in 2018 Stood at 30.5 Trillion Cubic Feet According to the Energy Information Administration. Available online: https://www.eia.gov/naturalgas/data.php (accessed on 14 August 2020).

45. Schmidt, O.; Gambhir, A.; Staffel, I.; Wahkes, A.; Nelson, J.; Few, S. Future Cost and Performance of Water Electrolysis: An Expert Elicitation Study. Int. J. Hydrogen Energy 2017, 42, 30470-30492. [CrossRef]

46. Trends in the Installed Cost of Wind Turbines Can Be Found in the US DOE. Available online: http: //www.eia.govorinthewindtradedata-base (accessed on 14 August 2020).

47. McGrath, M.E.; Hoole, R.W. Manufacturing's New Economies of Scale. The Harvard Business Review, 19 June 1992; 94-102.

48. Gasoline Use in the US in 2018 Stood at 143 Billion Gallons. Available online: https://www.eia.gov/tools/faqs/ faq.php?id=23\&t=10 (accessed on 14 August 2020).

49. Ingersoll, J.G. Ibid. In Addition to the Remaining 3o million Dry mt/yr Hog Manure and Poultry Litter There Exist Annual Collectable amounts of 129 million Dry mt of Cow Manure, 113 million Dry mt of cOrn Stover, 76 million mt of Wheat Straw, 53 million Dry mt of Soybean Straw and 41 Dry mt of Barley, Oats, Sorghum and Sugarcane Crop Residues. 2010. Available online: www.xlibris.com (accessed on 14 August 2020).

(C) 2020 by the author. Licensee MDPI, Basel, Switzerland. This article is an open access article distributed under the terms and conditions of the Creative Commons Attribution (CC BY) license (http://creativecommons.org/licenses/by/4.0/). 